\title{
Vitamin C as a Possible Therapy for COVID-19
}

\section{Hemilä, Harri}

2020-06

Hemilä , H \& Chalker , E 2020 , ' Vitamin C as a Possible Therapy for COVID-19 ' , Infection \& chemotherapy , vol. 52 , no. 2 , pp. 222-223 . https://doi.org/10.3947/ic.2020.52.2.222

http://hdl.handle.net/10138/317374

https://doi.org/10.3947/ic.2020.52.2.222

cc_by

publishedVersion

Downloaded from Helda, University of Helsinki institutional repository.

This is an electronic reprint of the original article.

This reprint may differ from the original in pagination and typographic detail.

Please cite the original version. 


\section{Correspondence}

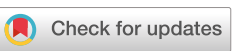

\title{
Vitamin C as a Possible Therapy for COVID-19
}

\author{
Harri Hemilä ${ }^{1}$ and Elizabeth Chalker ${ }^{2}$ \\ 'Department of Public Health, University of Helsinki, Helsinki, Finland \\ ${ }^{2}$ School of Public Health, University of Sydney, Sydney, Australia
}

\section{OPEN ACCESS}

Received: May 7, 2020

Accepted: May 9, 2020

Corresponding Author:

Harri Hemilä, MD, PhD

Tukholmankatu 8B, Department of Public Health, University of Helsinki, РОВ 41, Helsinki, FI-00014, Finland.

E-mail: harri.hemila@helsinki.fi

Copyright (c 2020 by The Korean Society of Infectious Diseases, Korean Society for Antimicrobial Therapy, and The Korean Society for AIDS

This is an Open Access article distributed under the terms of the Creative Commons Attribution Non-Commercial License (https:// creativecommons.org/licenses/by-nc/4.0/) which permits unrestricted non-commercial use, distribution, and reproduction in any medium, provided the original work is properly cited.

ORCID iDs

Harri Hemilä

https://orcid.org/0000-0002-4710-307X

Elizabeth Chalker

https://orcid.org/0000-0003-1593-3770

Conflict of Interest

No conflicts of interest.

\section{Author Contributions}

Conceptualization: HH, EC. Writing - original draft: HH. Writing - review \& editing: HH, EC.

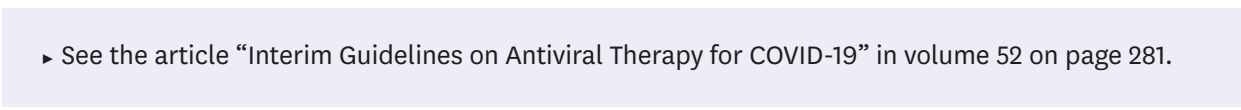

Dear Editor,

Kim et al. reviewed potential therapeutic approaches against coronavirus diseases 2019 (COVID-19) [1]. We would like to propose that vitamin C should also be included as a possible treatment as it has numerous effects on the immune system [2, 3].

In a meta-analysis of 29 controlled trials with 11,306 participants, we showed that regular vitamin $\mathrm{C}$ intake of around $1 \mathrm{~g}$ /day did not prevent upper respiratory tract infections (URTIs) [4]. However, the same trials found that vitamin C shortened and alleviated URTIs that occurred during the period of vitamin $\mathrm{C}$ administration. In adults the duration of infections was reduced by $8 \%$ and in children by $14 \%$ [4]. Given the low frequency and usually mild symptoms of URTIs, and the relatively small benefit, prophylactic daily vitamin C dosing does not seem worthwhile under normal circumstances. However, noting that many URTIs are caused by endemic coronaviruses, there is no reason or evidence to assume that vitamin $\mathrm{C}$ would be completely ineffective against COVID-19. Given that COVID-19 is often much more severe than ordinary URTIs, the above estimates might justify a regular increased daily intake of vitamin C while the prevalence of COVID-19 is high.

Furthermore, one of the major causes for concern with COVID-19 is the relatively high proportion of cases requiring intensive care unit (ICU) treatment. A meta-analysis of 12 trials with 1,766 patients in ICU found that vitamin C shortened ICU stay by $8 \%$ [5]. Another metaanalysis of eight trials found that vitamin $\mathrm{C}$ shortened the duration of mechanical ventilation in patients who required the longest ventilation [6]. There is evidence that vitamin C levels decline dramatically in critically ill patients $[5,7]$. Although $0.1 \mathrm{~g} /$ day of vitamin $\mathrm{C}$ can maintain a normal plasma level in a healthy person [8], much higher doses $(1-4 \mathrm{~g} /$ day $)$ are needed to increase plasma vitamin $\mathrm{C}$ levels of critically ill patients to within the normal range $[5,9]$. Vitamin $C$ is a safe and inexpensive essential nutrient and therefore investigation of its possible effects on COVID-19 should be encouraged along with the several other potential treatments [1]. 


\section{REFERENCES}

1. Kim SB, Huh K, Heo JY, Joo EJ, Kim YJ, Choi WS, Kim YJ, Seo YB, Yoon YK, Ku NS, Jeong SJ, Kim SH, Peck KR, Yeom JS. Interim guidelines on antiviral therapy for COVID-19. Infect Chemother 2020;52:281-304. PUBMED | CROSSREF

2. Manning J, Mitchell B, Appadurai DA, Shakya A, Pierce LJ, Wang H, Nganga V, Swanson PC, May JM, Tantin D, Spangrude GJ. Vitamin C promotes maturation of T-cells. Antioxid Redox Signal 2013;19:2054-67. PUBMED | CROSSREF

3. Carr AC, Maggini S. Vitamin C and immune function nutrients. Nutrients 2017;9:1211. CROSSREF

4. Hemilä H, Chalker E. Vitamin C for preventing and treating the common cold. Cochrane Database Syst Rev 2013;(1):CD000980.

PUBMED | CROSSREF

5. Hemilä H, Chalker E. Vitamin C can shorten the length of stay in the ICU: a meta-analysis. Nutrients 2019;11:E708. PUBMED | CROSSREF

6. Hemilä H, Chalker E. Vitamin C may reduce the duration of mechanical ventilation in critically ill patients: a meta-regression analysis. J Intensive Care 2020;8:15. PUBMED | CROSSREF

7. Carr AC, Rosengrave PC, Bayer S, Chambers S, Mehrtens J, Shaw GM. Hypovitaminosis C and vitamin $\mathrm{C}$ deficiency in critically ill patients despite recommended enteral and parenteral intakes. Crit Care 2017;21:300. PUBMED | CROSSREF

8. Levine M, Conry-Cantilena C, Wang Y, Welch RW, Washko PW, Dhariwal KR, Park JB, Lazarev A, Graumlich JF, King J, Cantilena LR. Vitamin C pharmacokinetics in healthy volunteers: evidence for a recommended dietary allowance. Proc Natl Acad Sci U S A 1996;93:3704-9. PUBMED | CROSSREF

9. de Grooth HJ, Manubulu-Choo WP, Zandvliet AS, Spoelstra-de Man AM, Girbes AR, Swart EL, Oudemans-van Straaten HM. Vitamin C pharmacokinetics in critically ill patients: a randomized trial of four iv regimens. Chest 2018;153:1368-77.

PUBMED | CROSSREF 